\title{
The Effect of Infusion of Syzygium polyanthum (Wight) Walp. Leaves as Natural Preservative Chicken Meats
}

\author{
Efek Infusa Daun Salam (Syzygium polyanthum (Wight) Walp.) sebagai Pengawet Alami \\ Daging Ayam
}

\author{
Dwi Hartanti $^{{ }^{*}}$, Asmiyenti Djaliasrin Djalil ${ }^{1}$, Nur Yulianingsih ${ }^{1}$, Alwani Hamad ${ }^{2}$ \\ ${ }^{1}$ Faculty of Pharmacy, Universitas Muhammadiyah Purwokerto, Purwokerto, Indonesia \\ ${ }^{2}$ Department of Chemical Engineering, Faculty of Engineering and Science, Universitas Muhammadiyah \\ Purwokerto \\ *E-mail: $\underline{\text { dwihartanti@ump.ac.id }}$
}

Diterima: 3 Januari 2019

Direvisi: 5 Februari 2019

Disetujui: 18 Februari 2019

\begin{abstract}
Syzygium polyanthum (Wight) Walp. (Indonesian bay leaf) is known for possessing antimicrobial activity that might be applied for natural food preservative. In this study, we analyzed the constituents of infusion of $S$. polyanthum leaves and evaluated its potency as the preservative of fresh chicken meats. The infusions were prepared with the method described in Indonesian Pharmacopeia. Phytochemical content of infusion of $S$. polyanthum leaves was analyzed by qualitative phytochemical screening using colorimetric methods. Its application for preservative of fresh chicken meat was evaluated based on its activity in inhibiting the growth of bacteria on the meats as well as the physical observation of the preserved meats. The infusion of S. polyanthum leaves contained flavonoids, tannins, and saponins. The infusion at the optimum concentration of $10 \%$ was capable of inhibiting bacterial growth on chicken meats and extending their shelf life up to 3 days in temperature of $3-7^{\circ} \mathrm{C}$.
\end{abstract}

Keywords: Chicken meat; Syzygium polyanthum; Infusion; Natural preservative

\begin{abstract}
Abstrak
Salam (Syzygium polyanthum (Wight) Walp.) telah diketahui memiliki aktivitas antimikroba, yang memungkinkan tumbuhan tersebut untuk dikembangkan menjadi pengawet makanan alami. Penelitian ini bertujuan untuk mengetahui kandungan kimia dan potensi infusa daun salam sebagai pengawet alami daging ayam. Kandungan kimia infusa daun salam dianalisis dengan menggunakan metode penapisan fitokimia. Potensi infusa daun salam sebagai pengawet alami daging ayam ditentukan berdasarkan aktivitasnya dalam menghambat pertumbuhan bakteri pada daging ayam dan juga pengamatan terhadap kondisi fisik daging yang diawetkan. Penapisan fitokimia menunjukkan bahwa infusa daun salam mengandung flavonoid, tanin, dan saponin. Infusa daun salam pada konsentrasi optimum $10 \%$ mampu menghambat pertumbuhan bakteri pada daging ayam selama penyimpanan dan memperpanjang masa simpannya hingga 3 hari pada suhu $3-7^{\circ} \mathrm{C}$.
\end{abstract}

Kata kunci: Daging ayam; Syzygium polyanthum; Infusa; Pengawet alami 


\section{INTRODUCTION}

Syzygium polyanthum (Wight) Walp. (Indonesian bay leaf, salam in Bahasa Indonesia, Myrtaceae), is a spice commonly used in Indonesian culinary, typically as a spice for savory meals. It has been known for possessing antimicrobial activity and traditionally used to treat bacterial-related diarrhea. ${ }^{1,2}$ The extracts of $S$. polyanthum leaves were active as antibacterials and antifungals, it was reported for growth inhibition activity of Staphylococcus aureus, Bacillus subtilis, B. cereus, Pseudomonas aeruginosa, and Candida albicans. ${ }^{3-6}$ The essential oil of this plant also demonstrated antimicrobial activity against $B$. subtilis, $S$. aureus, Salmonella typhimurium, and Vibrio cholera. $^{7,8}$ The antimicrobial activity exhibited by $S$. polyanthum leaves might support its use as a natural food preservative. The use of spices as a food preservative is desirable. We are familiar with the flavor, aroma, and color of those spices so their use might enhance the reception level of the preserved food.

Fresh chicken meat is largely consumed worldwide. ${ }^{9}$ Its nature that is rich with protein and water enables the growth of microbes at room temperature. Chicken meat is easily damaged by microbial activity, so preservation is needed to extend the shelf life and ensure the quality of chicken meat. ${ }^{10}$ Campylobacter spp., E. coli, and Salmonella sp. were reported as the common contaminants of fresh poultry meat. ${ }^{11}$ The use of essential oil of spices as a natural preservative in chicken meat has been reported. ${ }^{12-15}$ However, the use of essential oils is not practical in the household setting for its preparation needs a special technique and relatively high cost expended. Hence, a more practical use of spices as natural fresh chicken meat needs to be studied further. In this paper, we report the chemical constituents and application of infusion of $S$. polyanthum leaves as a natural preservative of fresh chicken meat.

\section{MATERIALS AND METHODS Plant materials}

The leaves of $S$. polyanthum were collected from Banjarnegara, Indonesia. The leaves were dried at room temperature for seven days and ground into a fine powder using grinding machine. The plant was authenticated at Laboratory of Botany, Jenderal Soedirman University, Purwokerto, Indonesia.

\section{Infusion preparation}

Infusion of $S$. polyanthum leaves was prepared according to a common infusion preparation method. ${ }^{16}$ Infusion was prepared in four concentrations: $0 \%, 5 \%, 10 \%$, and $20 \%$. Ten percent infusion was prepared by weighing $10 \mathrm{~g}$ of powdered dry leaves and then adding it with $100 \mathrm{ml}$ of distilled water. Those materials were put in an infuse apparatus, and boiled for 15 minutes at a temperature of $90{ }^{\circ} \mathrm{C}$. The infusion was filtered and its volume was fixed into 100 $\mathrm{ml}$ with distilled water. Five and $20 \%$ infusions were prepared accordingly. Zero percent of infusion was a boiled distilled water in the same manner and used as the negative control in this study.

\section{Qualitative phytochemical screening}

The main constituents of infusion of $S$. polyanthum leaves were analyzed with the standard qualitative phytochemical screening method. ${ }^{17,18}$ Briefly, Zn-chloride acid, sulphuric acid, Dragendorf's reagent, and ferric chloride were used to identify flavonoids, terpenoids, alkaloids, and tannins, respectively. Formation of foam method was used to identify saponins in infusion.

\section{Preservative potency evaluation}

The fresh chicken meat used in this study was obtained from a local market at Purwokerto, Indonesia. They were cut in size of $1 \times 1 \times 1 \mathrm{~cm}$. Each piece was immersed in boiling water for 2 minutes to reduce the 
number of the microorganisms on their surfaces. Meats were placed in $100 \mathrm{ml}$ of 4 different concentrations of infusion of Syzygium polyanthum leaves under sterile condition, they were $0 \%, 5 \%, 10 \%$, and $20 \%$, respectively. The meats preserved in the infusion were stored at a temperature of $3-7^{\circ} \mathrm{C}$. On day $3,6,9$, and 12 , the bacterial growth on the meats was determined and their physical appearance was evaluated. On the respective observation days, meat from each cube was put in $25 \mathrm{ml}$ of sterile nutrient broth (NB) medium and then homogenized for a minute. One $\mathrm{ml}$ of suspension was transferred into $9 \mathrm{ml}$ of sterile NB and then incubated in temperature of $37^{\circ} \mathrm{C}$ for 24 hours. The optical densities of cultured bacterial suspensions were recorded with UV-Vis spectrophotometer at a wavelength of $600 \mathrm{~nm}$ for evaluating the indirect enumeration of bacterial growth. One $\mathrm{ml}$ of first mentioned suspension was also cultured on $15 \mathrm{ml}$ of nutrient agar (NA) to observe the direct growth of bacteria. The physical observation of the preserved meats includes the evaluation of odor, texture, and formation of slime to determine the shelf life of the meats compared to that treated with the negative control. ${ }^{19,20}$ All the works were replicated 3 times.

\section{Statistical analysis}

Means separation of the optical densities of cultured bacterial suspensions in NB was accomplished by Duncan's multiple range tests. Significance was evaluated at p-value $<0.05$. Statistical analysis was conducted by the general procedures of SPSS Statistics v.17 (SPSS Inc.).

\section{RESULT AND DISCUSSION}

Infusion of $S$. polyanthum leaves used in this study contained tannins, flavonoids, and saponins (Table 1). Water, as the solvent in our study is a strongly polar compound, extracted flavonoids and tannins which are relatively polar compounds contained in leaves of $S$. polyanthum. A less polar ethanolic extract of this plant contains alkaloids, saponins, quinines, phenols, triterpenoids, steroids, and flavonoids. ${ }^{21}$ Another report mentioned that the ethanolic extract of the plant obtained from Samarinda-Indonesia contains carbohydrates, tannins, alkaloids, steroids, triterpenoids, and flavonoid. ${ }^{22}$ Saponins were previously reported as the main constituents of infusion of $S$. polyanthum leaves grown in Bali. ${ }^{19}$

The antimicrobial activity of flavonoids, tannins, and saponins has been reported. Tannins from leaves of Samanea saman was responsible for its activity against $E$. coli. ${ }^{23}$ Another report also mentioned that polyphenol compounds including tannins and flavonoids from Jatropha curcas were the active compounds that supporting its use as an antimicrobial agent against $S$. aureus. ${ }^{24}$ Hence, those three groups of compounds contained in the infusion of $S$. polyanthum leaves might be responsible for the antibacterial activity and further meat preservative potency.

Table 1. The result of qualitative phytochemical screening analysis of infusion of $S$. polyanthum leaves

\begin{tabular}{|c|c|c|c|c|}
\hline \multirow{2}{*}{ Constituents } & \multirow{2}{*}{ Reagents } & \multicolumn{2}{|c|}{ Results } & \multirow{2}{*}{ Conclusion } \\
\hline & & Positive & Observed & \\
\hline Flavonoids & $\mathrm{Zn}-\mathrm{HCl}$ & formation of a red color & a red hue was formed & positive \\
\hline Terpenoids & $\mathrm{H}_{2} \mathrm{SO}_{4}$ & $\begin{array}{l}\text { formation of the transparent ring } \\
\text { on the surface of the upper layer }\end{array}$ & $\begin{array}{l}\text { brown color in the upper } \\
\text { layer was formed }\end{array}$ & negative \\
\hline Alkaloids & Dragendorf & formation of a brown color & $\begin{array}{l}\text { orange precipitation was } \\
\text { observed }\end{array}$ & negative \\
\hline Tannins & $\mathrm{FeCL}_{3}$ & formation of dark green color & $\begin{array}{l}\text { a dark green hue was } \\
\text { observed }\end{array}$ & positive \\
\hline Saponins & - & formation of stable foam & $\begin{array}{l}\text { the stable foam was } \\
\text { formed }\end{array}$ & positive \\
\hline
\end{tabular}




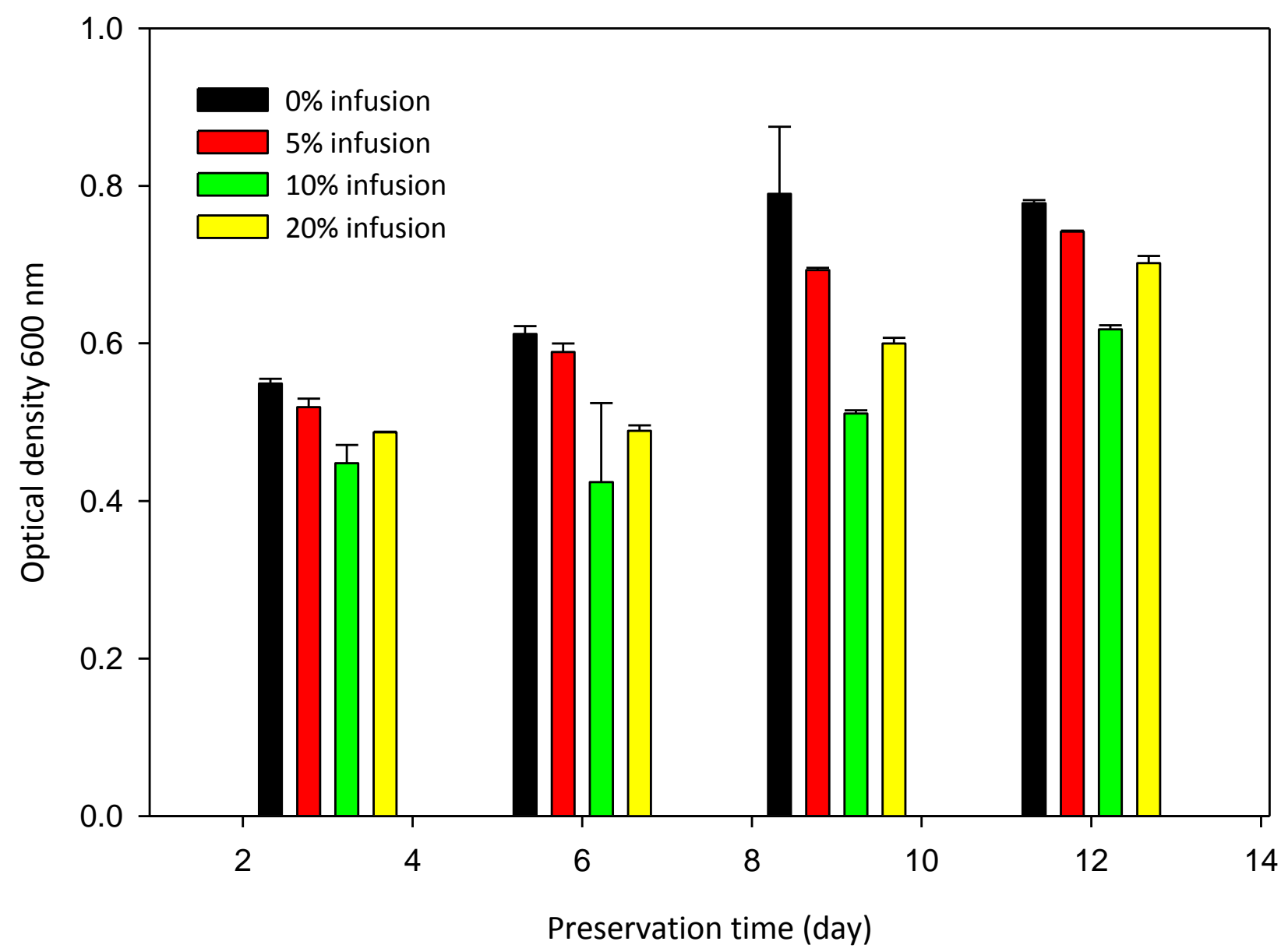

Figure 1. The profile of optical density of cultures of meats preserved with infusion of $S$. polyanthum leaves in NB media

The potency of the infusion of $S$. polyanthum leaves to preserve fresh chicken meat was evaluated by the indirect enumeration of microbial growth on the meat. The preservation with infusion in different concentrations affected the optical density of the samples, which represented the number of microbes grew on the meats. The degree of the increasing optical density, and hence the microbial growth on the meats, was different among treatments. On day 3 , there were no differences of optical densities between meats preserved with infusions of $S$. polyanthum leaves in all given concentrations and that of the negative control. This result indicated that bacterial growth in all given concentrations was equal with bacterial growth in negative control. It is assumed that the microbes on the meats were still in lag phase. Their number simply represented the initial microbial burden of the samples. On day 6 , the optical densities of samples in all treatments were increased. However, the meats preserved with $10 \%$ and $20 \%$ infusion of $S$. polyanthum leaves showed inhibition of bacterial growth, shown by a significantly different optical density compared to that of negative control (p-value < 0.05). There were increasing optical densities of all samples on day 9 and 12 compared to day 6. Nevertheless, all given concentrations of infusion were also significantly different from that in the negative control group. Hence, infusion of $S$. polyanthum leaves at concentrations of $5 \%$, $10 \%$, and $20 \%$ were capable of inhibiting the 
Table 2. Physical characteristic of the meats preserved with infusion of S. polyanthum leaves

\begin{tabular}{|c|c|c|c|c|c|}
\hline \multirow{2}{*}{ Treatment groups } & \multirow{2}{*}{ Physical characteristic } & \multicolumn{4}{|c|}{ Preservation time (day) } \\
\hline & & 3 & 6 & 9 & 12 \\
\hline \multirow[t]{3}{*}{$0 \%$ infusion } & odor & fresh & fresh & fresh & deteriorated \\
\hline & texture & firm & firm & friable & friable \\
\hline & slime & none & none & none & none \\
\hline \multirow[t]{3}{*}{$5 \%$ infusion } & odor & fresh, aromatic & fresh, aromatic & fresh, aromatic & fresh, aromatic \\
\hline & texture & firm & firm & friable & friable \\
\hline & slime & none & none & none & none \\
\hline \multirow[t]{3}{*}{$10 \%$ infusion } & odor & fresh, aromatic & fresh, aromatic & fresh, aromatic & fresh, aromatic \\
\hline & texture & firm & firm & firm & friable \\
\hline & slime & none & none & none & none \\
\hline \multirow[t]{3}{*}{$20 \%$ infusion } & odor & fresh, aromatic & fresh, aromatic & fresh, aromatic & fresh, aromatic \\
\hline & texture & firm & firm & firm & friable \\
\hline & slime & none & none & none & none \\
\hline
\end{tabular}

Note: Bold printed words indicated first changes of the physical characteristic for the given treatment groups.

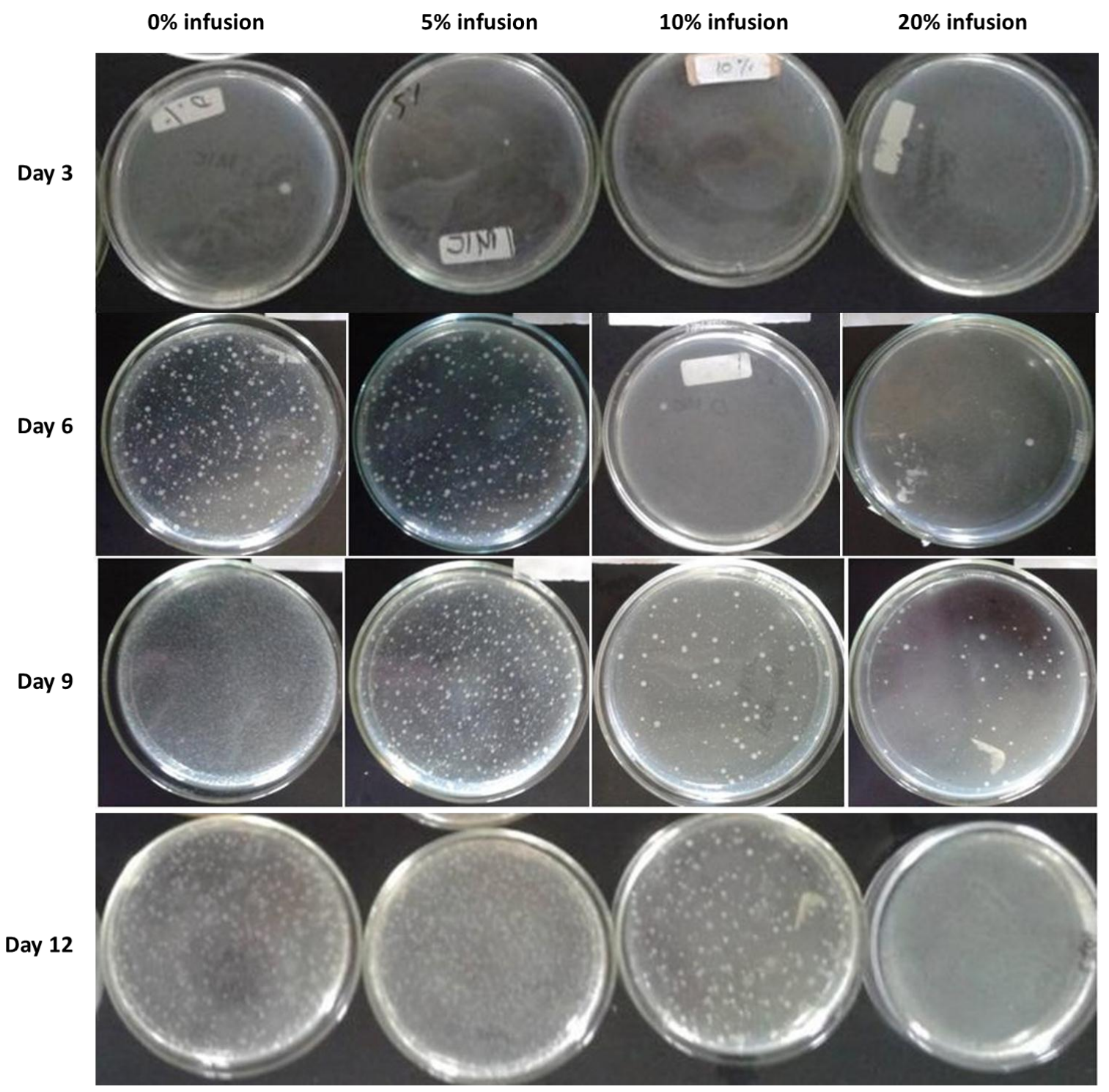

Figure 2. Bacterial growth on meats preserved with infusions of $S$. polyanthum leaves cultured in NA, on day 3, 6, 9, and 12 of preservation 
growth of bacteria on preserved meats compared to the negative control. This result demonstrated that the higher concentration of infusion, the better it inhibited the growth of the bacteria. However, infusion of $S$. polyanthum leaves in both concentrations of $10 \%$ and $20 \%$ demonstrated the equal bacterial growth inhibitory activity, as their optical densities in day 6,9 , and 12 were not statistically different (Figure 1).

We also evaluated the profile of direct growth of bacteria on the meat preserved with the infusion of $S$. polyanthum leaves on the NA medium to determine its preservation potency (Figure 2). In general, the number of bacterial colonies increased with the time of preservation, while a higher concentration of infusion generated a less bacterial colony. On day 3 , there was no visually microbial growth on meat observed at any given concentration of the extract. On day 6, bacterial growth was observed on meats in negative control and those preserved with $5 \%$, while those preserved with $10 \%$ and $20 \%$ of infusions were remained clear without microbial growth. On day 9, microbial growth was visually observed on meats preserved with infusions of $S$. polyanthum leaves at all given concentration. The most number of bacteria colony on preserved meats was observed in $0 \%$ of infusion, followed by those preserved with infusion at a concentration of 5\%,10\%, and $20 \%$, respectively. On day 12 , there was more microbial growth on meats compared to day 9. The result of this direct enumeration of the bacteria on the meats preserved with the infusions of $S$. polyanthum leaves demonstrated that the higher concentrations of the infusion, the better inhibitory activity was observed. Compared to the indirect enumeration method, the result was similar to a slight difference in $20 \%$ infusion. However, we did not quantitatively enumerate the bacterial counts and just utilized the limited visual observations so we could not confirm if the number of bacteria in meats preserved with
$10 \%$ infusion was truly less than that of $20 \%$ infusion.

In general, the use of infusions of $S$. polyanthum leaves changed the color of the meats from pinkish white to brownish. The higher concentration of infusion, the darker the meats preserved. We utilized a physical evaluation of the preserved meats to determine their shelf life with the treatment of infusion of $S$. polyanthum leaves (Table 2). Odor, texture, and formation of slime on the meats were used as the parameters observed and then compared to those treated with negative control. According to SNI 3924:2009 on the quality of carcass and meat of chicken, a good quality of chicken meats could be tested by visual and palpation evaluation. ${ }^{25}$ The fresh chicken meats should possess a consistent color, firm texture, and slime-free. All those characters were observed at the beginning of the preservation. There was a different odor between meats preserved with negative control and those preserved with infusion. The first mentioned groups were chickenfresh, whereas the later was fresh with a hint of specific aromatic odor from $S$. polyanthum. As more bacteria were observed (Figure 2), meats in negative control and those preserved with 5\% infusion group started to be friable at day 9 , while those preserved with infusion at higher concentrations started to change at day 12 . Hence, the infusion at a concentration of $5 \%$ was not capable of extending the shelf life of the meats. The odor of meats in negative control started to change at day 12 , while meats preserved with infusion at higher concentrations were remained fresh with the aromatic scent of $S$. polyanthum. It can be concluded that fresh chicken meat preserved with infusion of $S$. polyanthum leaves at concentrations of $10 \%$ and $20 \%$ are capable of extending shelf life up to 3 days longer than unpreserved fresh chicken meat.

Based on the inhibition of bacterial growth (both direct and indirect) and physical evaluation of the meats, infusion 
of $S$. polyanthum leaves was potential to be used as a natural preservative of fresh chicken meats. Infusions in both concentration of $10 \%$ and $20 \%$ demonstrated the same potency in inhibiting bacterial growth as well as physical changes of meats. However, we chose $10 \%$ as the optimal concentration of the infusion due to its color changed. The color of infusion at a concentration of $20 \%$ was dark brown and it changed the color of the meats. Darker-looked meat might be not preferable and has low acceptability. The infusion of $S$. polyanthum leaves could inhibit bacterial growth on meats at the optimum concentration of $10 \%$, as well as capable of extending the meats shelf life up to 3 days at a temperature of $3-7^{\circ} \mathrm{C}$ compared to that of the negative control group.

Our finding that infusion of $S$. polyanthum leaves can be used as fresh chicken meat was in accordance with previously reported data. The infusion of $S$. polyanthum leaves was capable of extending the shelf life and decreasing the total bacterial count of Broiler chicken meat at a concentration of $20 \%{ }^{26}$ and $10 \% .{ }^{27}$ Another report demonstrated that it was able to maintain the quality of pork up to 9 hours at room temperature storage. ${ }^{19}$

Our results demonstrated that the infusion of spices could be developed for natural preservatives. It might be studied further so it can be used as the alternative for essential oil of spices for that said purposes. Essential oils of spices were potential to be used as food preservatives but their use were limited by their unpractical preparation needed and insolubility in water. ${ }^{12,14,28-30}$

\section{CONCLUSION}

Infusion of $S$. polyanthum leaves at the optimum concentration of $10 \%$ was potential to be used as a natural preservative of fresh chicken meats. It was capable of inhibiting bacterial growth on meats during refrigerated storage and extending its shelf life up to 3 days.
Flavonoids, tannins, and saponins might be responsible for antibacterial activity accounted for this preservative potency.

\section{ACKNOWLEDGEMENT}

The authors acknowledge the Directorate General of Higher Education, Ministry of National Research and Higher Education, Indonesia for financial support.

\section{REFERENCES}

1. Ramli S, Radu S, Shaari K, Rukayadi Y. Antibacterial activity of ethanolic extract of Syzygium polyanthum L. (Salam) leaves against foodborne pathogens and application as food sanitizer. Biomed Res Int. 2017;2017:Article ID 9024246.

2. Malik A, Ahmad AR. Antidiarrheal activity of ethanolic extract of bay leaves (Syzygium polyanthum [Wight.] Walp.). Int Res J Pharm. 2013;4(4);106-108.

3. Murhadi, Suharyono AS, Susilawati. Aktivitas antibakteri ekstrak daun salam (Syzygium polyantha) dan daun pandan (Pandanus amaryfolius). J Teknol dan Ind Pangan. 2007;18(1):17-24.

4. Fitriani A, Hamdiyati Y, Engriyani R. Aktivitas antifungi ekstrak etanol daun salam (Syzygium polyanthum (Wight) Walp.) terhadap pertumbuhan jamur Candida albicans secara in vitro. Biosfera. 2012;29(2):71-9.

5. Lau KY, Zainin NS, Abas F, Rukayadi Y. Antibacterial and sporicidal activity of Eugenia polyantha Wight against Bacillus cereus and Bacillus subtilis. Int $\mathbf{J}$ Curr Microbiol Appl Sci. 2014;3(12):499-510.

6. Hamad A, Mahardika MGP, Istifah, Hartanti D. Antimicrobial and volatile compounds study of four spices commonly used in Indonesian culinary. J Food Pharm Sci. 2016;4(1):1-5.

7. Amalina N, Natanamurugaraj G, Mashitah MY, Ashikin AKN. Chemical composition, antioxidant and antibacterial activities of Syzygium polyanthum (Wight) Walp. essential oils. In: International Conference of Natural Products. 2013.

8. Hamad A, Mahardika MGP, Yuliani I, Hartanti D. Chemical constituents and 
antimicrobial activities of essential oils of Syzygium polyanthum and Syzygium aromaticum. Rasayan J Chem. 2017;10(2):564-9.

9. OECD. Meat consumption (indicator) [Internet]. OECD Data. 2019 [cited 2019 Feb 14]. Available from: https://data.oecd.org/agroutput/meatconsumption.htm

10. Dave D, Ghaly AE. Meat spoilage mechanism and preservation techniques: A critical review. Am J Agric Biol Sci. 2011;6(4):486-510.

11. Zhao C, Ge B, Villena J de, Sudler R, Yeh E, Zhao S, et al. Prevalence of Campylobacter spp., Escherichia coli, and Salmonella serovars in retail Chicken, Turkey, Pork, and Beef from Greater Washington D,C. area. Appl Environ Microbiol. 2001;67(12):5431-6.

12. Hyldgaard M, Mygind $T$, Meyer RL, Debabov D. Essential oils in food preservation: mode of action, synergies, and interactions with food matrix components. Front Microbiol. 2012;3(12):1-24.

13. Yadaf AS, Singh RP. Natural preservatives in poultry meat products. Nat Prod Radiance. 2004;3(4):300-3.

14. Fratianni F, Martino L De, Melone A, Feo $\mathrm{V}$ De, Coppola R, Nazzaro F. Preservation of chicken breast meat treated with thyme and balm essential oils. J Food Sci. 2010;75(8):M528-535.

15. Petrová J, Pavelková A, Hleba L, Pochop J, Rovná K, Katarina M. Microbiological quality of fresh chicken breast meat after Rosemary essential oil treatment and vacuum packaging. Anim Sci Biotechnol. 2013;46(1):140-4.

16. Anonymous. Farmakope Indonesia. 4th ed. Jakarta: Departemen Kesehatan Republik Indonesia; 1995.

17. Patel MR, Panchal HS, Saluja AK. Identification of terpenoids and steroidal compounds in Caryota urens leaves by column chromatography and various spectroscopic techniques. World J Pharm Pharm Sci. 2016;5(5):1610-22.

18. Zohra SF, Meriem B, Samira S, Muneer MSA. Phytochemical screening and identification of some compounds from mallow. J Nat Prod Plant Resour. 2012;2(4):512-6.

19. Agustina KK, Sari PH, Suada IK.
Pengaruh perendaman pada infusa daun salam terhadap kualitas dan daya tahan daging babi. Bull Vet Udayana. 2017;9(1):34-41.

20. De-Azeredo GA, Stamford TLM, Nunes PC, Neto NJG, de Oliviera MEG, de Souza EL. Combined application of essential oils from Origanum vulgare L. and Rosmarinus officinalis L. to inhibit bacteria and autochthonous microflora associated with minimally processed vegetables. Food Res Int. 2011;44:15418.

21. Hasanah N. Aktivitas antioksidan ekstrak etanol daun salam. J Pena Med. 2015;5(1):55-9.

22. Kusuma IW, Kuspradini H, Arung ET, Aryani F, Min Y, Kim J, et al. Biological activity and phytochemical analysis of three Indonesian medicinal plants, Murraya koenigii, Syzygium polyanthum and Zingiber purpurea. J Acupunct Meridian Stud 2011;4(1):75-9.

23. Sari PP, Rita SW, Puspawati MN. Identifikasi dan uji aktivitas senyawa tanin dari ekstrak daun Trembesi (Samanea saman (Jacq.) Merr) sebagai antibakteri Escherichia coli. J Kim. 2015;9(1):27-34.

24. Nuria CM, Faizatun A, Sumantri. Uji aktivitas antibakteri ekstrak etanol daun jarak pagar (Jatropha curcas L) terhadap bakteri Staphylococcus aureus ATCC 25923, Escherichia coli ATCC 25922, dan Salmonella Typhi ATCC 1408. J Ilmu Pertan. 2009;5(2):26 - 37.

25. BSN. SNI 3924:2009 Mutu karkas dan daging ayam. Badan Standar Nasional; 2009. p. 1-7.

26. Pura EA, Suradi K, Suryaningsih L. Pengaruh berbagai konsentrasi daun salam (Syzygium polyanthum) terhadap daya awet dan akseptabilitas pada karkas ayam broiler. J Ilmu Ternak. 2015;15(2):2-7.

27. Kusumaningrum A, Widiyaningrum $P$, Mubarok I. Penurunan total bakteri daging ayam dengan perlakuan perendaman infusa daun salam (Syzygium polyanthum). J MIPA. 2013;36(1):14-9.

28. Andayani T, Hendrawan Y, Yulianingsih R. Minyak atsiri daun sirih merah (Piper crocatum) sebagai pengawet alami pada ikan teri (Stolephorus indicus). J Bioproses Komod Trop. 2014;2(2):123- 
30.

29. Hamad A, Hartanti D. The use of essential oil of Clove (Syzygium aromaticum) as Tofu's natural preservative. Farmasains. 2015;2(6):28994.

30. Prakash B, Kedia A, Mishra PK, Dubey
NK. Plant essential oils as food preservatives to control moulds, mycotoxin contamination and oxidative deterioration of agri-food commodities Potentials and challenges. Food Control. 2015;47:381-91. 